Retraction

\title{
Retracted: Chemical Speciation and Potential Mobility of Heavy Metals in the Soil of Former Tin Mining Catchment
}

\author{
The Scientific World Journal \\ Received 4 June 2018; Accepted 4 June 2018; Published 12 December 2018 \\ Copyright @ 2018 The Scientific World Journal. This is an open access article distributed under the Creative Commons Attribution \\ License, which permits unrestricted use, distribution, and reproduction in any medium, provided the original work is properly \\ cited.
}

At the request of the authors, the article titled "Chemical Speciation and Potential Mobility of Heavy Metals in the Soil of Former Tin Mining Catchment" [1] has been retracted. The article has a high similarity index.

\section{References}

[1] M. A. Ashraf, M. J. Maah, and I. Yusoff, "Chemical speciation and potential mobility of heavy metals in the soil of former tin mining catchment," The Scientific World Journal, vol. 2012, Article ID 125608, 11 pages, 2012. 